\title{
Recurrent metastasis of progressive parachordoma of spermatic duct to different sites in a year: $\mathrm{A}$ rare case
}

\author{
Progresif spermatik kanal parakordomasının vücudun farklı kısımlarına bir yıl içinde \\ tekrarlayan metastazları: Nadir bir olgu
}

Mehmet Erol Yıldırım ${ }^{1}$, Hüseyin Şahin ${ }^{2}$, Hüseyin Badem ${ }^{1}$, Ersin Çimentepe $^{1}$, Cenap Dener $^{2}$

\begin{abstract}
Parachordoma is a rare entity with an unknown origin, which reported nearly in 60 cases. We are reporting an aggressive tumor that has two recurrences in 5 months in different sites. A 49 year old male admitted with right inguinal pain that underwent a computed tomography, revealed a $52 \times 50 \mathrm{~mm}$ tumor at the right inguinal subepidermal region. After the resection, pathology of the mass was parachordoma. Four months after the operation, patient admitted with a solitary mass in the right testis. Ultrasonography revealed four different masses in the right inguinal and right testicular region. Second pathology results were also parachordoma. One month later the second operation, patient again admitted to hospital with right hip pain, had a solitary mass on the collum femoris in the magnetic resonance imaging consulted for radiotherapy. Parachordoma is a rare, benign entity that must be closely followed up. The physician must be aware of the malignancy especially in the first year with existence of recurrence and metastasis. Radiotherapy is recommended after maximal resection of tumor especially in metastatic cases. J Clin Exp Invest 2013; 4 (3): 377-379
\end{abstract}

Key words: Parachordoma, pelvic tumor, radiotherapy

\section{INTRODUCTION}

Parachordoma is a soft tissue tumor with an unknown origin that proposed as mixed tumor and myoepithelioma at 2002 by World Health Organization [1]. Parachordoma was first reported by Laskowski in 1959 as a peripheral chordoma and there are about only 50-60 cases reported in the recent literature [2]. This report presents the third case as pelvic parachordoma with unusual aggressive be-

\section{ÖZET}

Bugüne kadar yaklaşık olarak 60 parakordoma vakası bildirilmiştir. Parakordoma etyolojisi tam olarak bilinmeyen nadir bir antitedir. Biz burada 5 ay içinde vücudun 2 farklı yerine metastaz yapan, agresif bir tümör olgumuzu paylaşmak istedik. Sağ inguinal ağrı ile hastanemize başvuran 49 yaşındaki erkek hastanın çekilen tüm abdomen tomografisinde sağ inguinal subepidermal sahada 52×50 $\mathrm{mm}$ çapında kitle tespit edildi. Eksize edilen kitlenin patolojik tanısı parakordoma olarak bildirildi. Operasyondan 4 ay sonra hasta ağrısız sağ testiküler kitle ile tekrar başvurdu. Yapılan ultrasonografide sağ inguinal bölgede 3 ve sağ testiste olmak üzere 4 adet kitle saptandı. Orşiektomi ve kitlelerin eksizyonu sonrasında patoloji yine parakordoma olarak geldi. İkinci operasyondan 1 ay sonra hasta sağ kalça ağrısı ile başvurdu ve yapılan manyeik rezonans incelemede sağ femur başında kitle tespit edildi. Biyopsi neticesinde parakordoma metastazı olması üzerine radyoterapi alması için radyasyon onkolojisine konsülte edildi. Parakordoma genelde nadir ve iyi huylu olmakla birlikte, özellikle ilk sene içindeki metastaz ve rekürrensler malign potansiyel açısından dikkate alınmalıdır. Özellikle metastatik olgularda, tümörün en geniş şekilde rezeksiyonunu takiben de radyoterapi önerilmektedir.

Anahtar kelimeler: Parakordoma, pelvik tümör, radyoterapi

havior and two times metastasis at five month period.

\section{CASE}

A 49-year-old male admitted to urology clinic with a painless growing mass in the right inguinal region lasting for a month. He had no significant medical or surgical history. A three $\mathrm{cm}$ mass palpated at the right inguinal region during physical examina-

${ }^{1}$ Turgut Özal University, School of Medicine, Department of Urology, Ankara, Turkey

${ }^{2}$ Turgut Özal University, School of Medicine, Department of General Surgery, Ankara, Turkey

Correspondence: Hüseyin Sahin,

Turgut Özal Üniversitesi, Tıp Fakültesi, Genel Cerrahi AD, Emek, Ankara, Turkey Email: kazangap84@hotmail.com

Received: 28.04.2013, Accepted: 28.05.2013

Copyright (C JCEI / Journal of Clinical and Experimental Investigations 2013, All rights reserved 


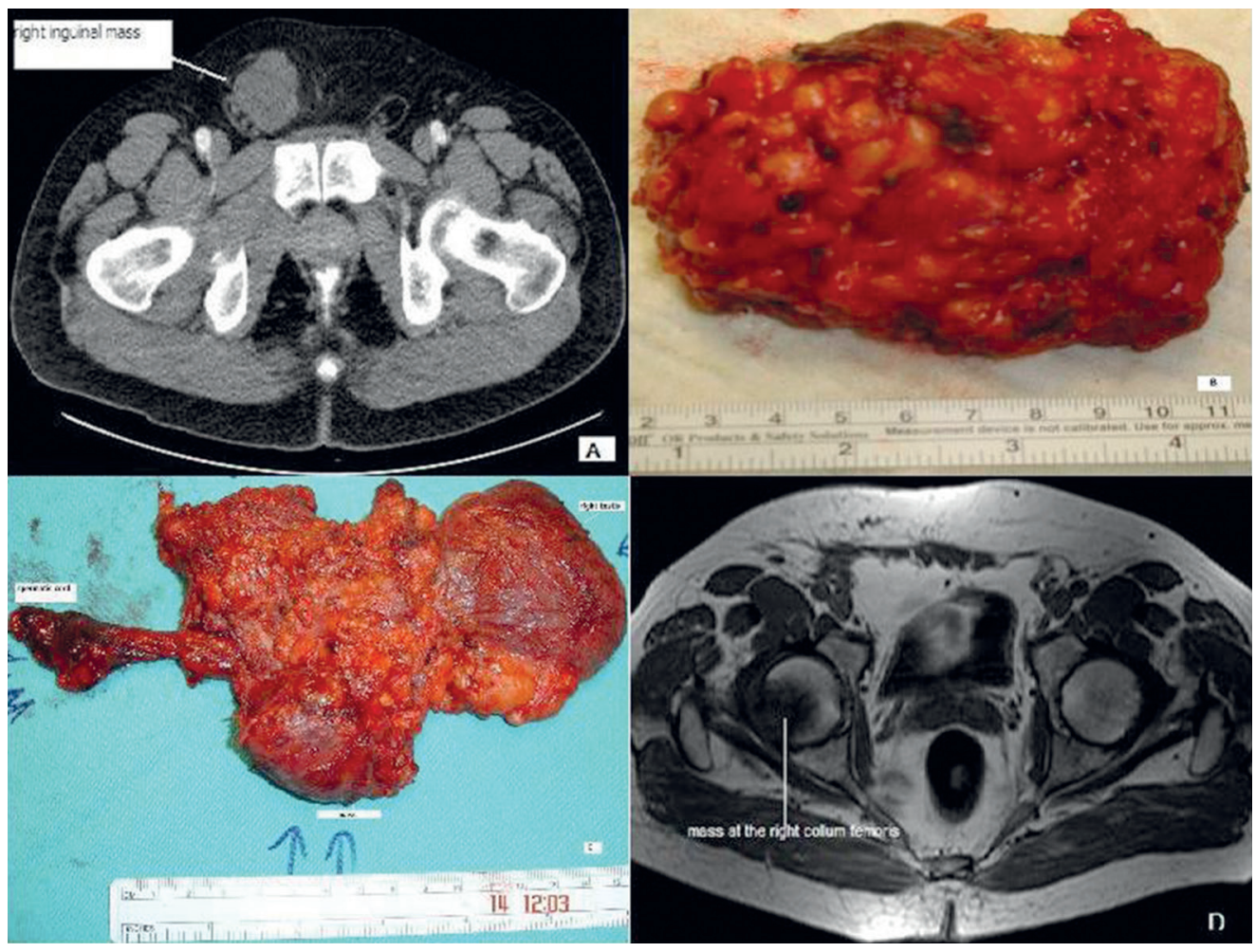

Figure 1. A) Abdominal $\mathrm{CT}$ image of the right inguinal mass before the first operation; B) mass resected at the first operation; C) mass and right testis resected at the second operation; D) MR image of the lesion at the right collum femoris

tion. Ultrasonography (USG) revealed a $35 \times 26 \mathrm{~mm}$ heterogeneous semisolid mass at the right inguinal region. A computed tomography (CT) scan showed a lobular lesion of $52 \times 50 \mathrm{~mm}$, undistinguished from the right spermatic cord, at the right side of the midline upper to the symphisis pubis in the sub epidermal fat tissue (Figure 1-A). Urology consulted the patient to general surgery clinic. After the hystopathologic report of mixoid malign mesenchyme tumor by the tru cut biopsy, we resected the inguinal mass largely and repaired the inguinal region with prolen mesh graft (Figure 1-B). Histopathology of the resected mass was parachordoma with negative surgical margin and positive vascular invasion. We decided to follow up the patient however there was no tumor invasion at PET-CT scan. In the postoperative fourth month, patient admitted with a solid mass at right spermatic cord, superior to the right testis. Doppler USG revealed a lobular lesion at the right spermatic cord with increased blood flow, two lobular lesions at the right inguinal region and another solid mass in the sub epidermal fat tissue nearby the right radix penis with increased blood flow. These tumors resected with right orchiectomy due to the preoperative parachordoma report of the tru cut biopsy (Figure 1-C). Parachordoma reported by pathology with negative surgical margin, positive vascular invasion and necrosis widespread. In the first mount after the second operation the patient admitted again with right hip pain. X-ray showed nothing but magnetic resonance imaging showed a $2 \times 1,5 \mathrm{~cm}$ T2 hyper intense lesion at the posterior side of collum femoris. This lesion was hypo intense on weighted image and enhancing homogeneously in post contrast (Figure 1-D). A tru cut biopsy taken with guidance of CT comprised malignant cells. We consulted the patient to the department of radiation oncology for radiotherapy with our close follow-up.

\section{DISCUSSION}

Parachordoma is an rare adult benign soft tissue tumor, however recurrence and metastasis are merely reported [3]. It is first reported by Laskows$\mathrm{ki}$ in 1959 [4]. There is a slight male dominancy in parachordoma [4]. The average age is about 34.4 years [range $4-86$ years old], however $20 \%$ of the patients are children in reported cases [2,5]. Our patient was 49 years old male. The common localizations of the parachordoma are the extremities, head, neck, torax, bones and rarely in the pelvis. This is the third parachordoma case that has been seen in the pelvis.

Tumor is characterized with painless and slow progression, but our patient admitted to us three times with pain in six-month period. It is well circumscribed and pseudo capsulated with a thin fibrous tissue. It is usually $2-7 \mathrm{~cm}$ in size but can grove up 
to $12 \mathrm{~cm}$ [4]. Patient's first tumor size was $7 \mathrm{~cm}$ and second was $3 \mathrm{~cm}$ respectively. It is curable with resection but sometimes recurrences and metastasis may occur from the tumor negative margins. Even its slow growth and locally invasive pattern, mortality with recurrence and metastasis in a year can be seen rarely [4]. There are only two deaths from metastatic parachordoma in the literature; however, some authors called parachordomas as low-grade sarcomas [7].

Our patient presented with left inguinal pain and we have seen two recurrences and distant metastasis in a 5 months period. First recurrence was 4 months after the first surgery at the same area and the second recurrence was at the collum femoris. Although the difficulty of resection of femur metastasis we decided to treat the patient with the pelvic radiotherapy. Recurrence reported at 3, 6 and 12 months by Niezabitowski, Carstens and Ishida respectively $[8,9]$. There is not a long follow up especially about pelvic metastatic parachordoma in the literature. Adjuvant radiotherapy is usually proposed after maximal resection of the tumor [10]. After comparing with other forms of radiation therapy, they advocated proton beam therapy as a better tool used to increase the dose delivered to the tumor while elegantly sparing dosing to adjacent critical normal structures.

Parachordoma is a rare entity that can affect any site of the body. Imaging can direct us to the tumor but exact diagnose could only be made by the pathologist. A correct diagnosis has definite therapeutic implications. Multidisciplinary diagnose must be done. Radiotherapy should be kept in mind for the metastatic cases at the first year of diagnose.

\section{REFERENCES}

1. Weiss SW, Goldblum JR: Enzinger \& Weiss's Soft Tissue Tumors. 5th ed., Philadelphia, Mosby Elsevier, 2008,1109-1116.

2. Tirabosco R, Mangham DC, Rosenberg AE, et al. Brachyury expression in extra-axial skeletal and soft tissue chordomas: a marker that distinguishes chordoma from mixed tumor/myoepithelioma/parachordoma in soft tissue. Am J Surg Pathol 2008;32:572-580.

3. Sangueza OP, White CR Jr. Parachordoma. Am J Dermatopathol 1994;16:185-188.

4. Karakaya YA, Özekinci S, Büyükbayram H, Mızrak B. Parachordoma: A Recurrent Case and Review of the Literature. Turk Patoloji Derg 2011;27:173-176.

5. Lococo F, Cesario A, Meacci E, et al. Pulmonary metastases from parachordoma Ann Thorac Surg 2009;88:9-10.

6. Dabska M. Parachordoma: A new clinicopathologic entity. Cancer 1977;40:1958-1992.

7. Clabeaux J, Hojnowski L, Valente A, Damron TA. Case report: parachordoma of soft tissues of the arm. Clin Orthop Relat Res 2008;466:1251-1256.

8. Fisher C, Miettinen M. Parachordoma: a clinicopathologic and immunohistochemical study of four cases of an unusual soft tissue neoplasm. Ann Diagn Pathol 1997;1:3-10

9. Ishida T, Oda H, Oka T, et al. Parachordoma: an ultrastructural and mmunohistochemical study. Virchows Arch A Pathol Anat Histopathol 1993;422:239-245.

10. Nguyen QN, Chang EL. Emerging role of proton beam radiation therapy for chordoma and chondrosarcoma of the skull base. Curr Oncol Rep 2008;10:338-343. 